\title{
Serum total Calcium level in patients with Thalassemia
}

\author{
Bandebuche $\mathbf{S}^{1}$, Sagar $\mathrm{V}^{2}$, Sontakke $\mathrm{A}^{3}$ \\ ${ }^{1}$ Dr. Sanjyoti Bandebuche, Assistant Professor Department of Biochemistry, ${ }^{2} \mathrm{Mr}$ Vijaykumar Sagar, UG Student, ${ }^{3}$ Dr Alka \\ Sontekke, Professor \& Head, Department of Biochemistry, all from MIMER Medical College, Talegaon Dabhade, \\ Maharashtra, India
}

Address for correspondence: Dr Sanjyoti Bandebuche, Email: psanjyoti@gmail.com

\begin{abstract}
Introduction: Thalassemia is a genetic disorder characterized by the complete absence or reduced synthesis of $\alpha$ or $\beta$ globin chains. The mainstay of treatment of severe $\beta$ thalassemia is regular blood transfusion. Repeated blood transfusion results in hypoparathyroidism and in turn hypocalcemia due to iron overload. The aim of the study was to evaluate calcium status in thalassemia patients by estimating and comparison of serum total calcium and iron levels between normal and thalassemic patients. Methods: The study comprised of clinically diagnosed $\beta$ thalassemia Major patients and age matched controls. Results: The results revealed stastically significant decrease in serum total calcium in thalassemia patients as compared to normal while serum iron levels found to be increased indicating iron toxicity. Discussion: On diagnosis as well as periodic assessment of thalassemia patients for hypocalcemia may be beneficial and if found calcium and vitamin D supplementation may be carried out in order to improve their bone health.
\end{abstract}

Key words: Calcium, Thalassemia, Iron, Hypoparathyroidism.

\section{Introduction}

Thalassemia is a heterogeneous family of inherited disorders of hemoglobin synthesis. It is characterized by the complete absence or reduced synthesis of one or more types of globin chains. There are two main types of thalassemia:

- Alpha thalassemia occurs when a gene or genes related to the alpha globin protein are missing or changed (mutated).

- Beta thalassemia occurs when similar gene defects affect production of the beta globin protein. The affected infants present with pallor, poor growth, and abdominal enlargement due to hepatosplenomegaly. In untreated children, characteristic bone changes appear, such as

Manuscript received: $10^{\text {th }}$ Aug 2013

Reviewed: $16^{\text {th }}$ Aug 2013

Author Corrected: $10^{\text {th }}$ Sep 2013

Accepted for Publication: $11^{\text {st }}$ Oct 2013 thinning of cortex of long bones, widening of medullary spaces, bossing of skull, widening of diploic spaces, and prominence of the upper incisors and separation of orbit ${ }^{1,2}$.

The mainstay of treatment of severe $\beta$ thalassemia is regular blood transfusion with an attempt, to maintain hemoglobin levels greater than $10 \mathrm{~g} / \mathrm{dl}^{3}$. Repeated blood transfusion results too much iron which in turn can result in damage to the heart, liver and endocrine system, which includes glands that produce hormones that regulate processes throughout the body ${ }^{4,5,6}$. For example iron deposition in the parathyroid gland, which in turn may cause hypoparathyroidism. As a result of hypoparathyroidism, low serum calcium levels have been reported in such patients and showing symptoms of hypocalcemia. Though the life expectancy of patients with

Available online at: www.ijmrr.in 190 | P a g e


thalassemia has greatly improved over the last decade as a result of regular transfusions and increased compliance with iron chelation therapy, however, this improvement is often accompanied by a series of serious complications including osteopenia and osteoporosis ${ }^{7}$. Calcium is an essential mineral for building and maintaining strong bones and teeth.

Having strong bones is important for all of us, but it is especially important for people with thalassemia. Limited studies have also shown that supplementation with vitamin $\mathrm{D}$ and calcium improves serum calcium status in turn bone health. Hence the study was planned to estimate serum total calcium levels in patients with thalassemia (major) The main aim of the study was to see the calcium status in thalassemia major patients by estimating serum total calcium in normal and thalassemia patients and estimating of serum iron and total iron binding capacity (TIBC) for iron overload in normal and thalassemia patients and comparison of calcium and iron status between normal and thalassemia patients.

\section{Material and Methods}

As the prevalence of $\beta$-thalassemia in India is approximately $3.3 \%$, the study was a observational case series which includes thalassemia patients attending paediatric Out Patients Department \& In Patients Department of Paediatric of Bhausaheb Sardesai Talegaon rural Hospital. The present study was also approved by the MIMER Medical College ethical committee.

\section{Inclusion Criteria:}

Cases - Clinically diagnosed $\beta$ thalassemia (major) patients aged between $(8-12)$ years and those receiving regular blood transfusion without calcium and vitamin D supplementation. Controls - Accordingly normal individuals were selected at random after matching age.

\section{Exclusion criteria:}

1. Very sick patients

2. Those receiving Calcium and Vitamin D supplementation

3. Patients associated with other major illness like Diabetes mellitus, Hypertension, Cardiovascular disorders, Liver and

kidney disorders.

Sample Collection: About $5 \mathrm{ml}$ of fasting venous blood was collected with all aseptic precautions in plain bulb with informed consent of parents. Separated serum was used for measurement of Serum total calcium, serum iron and TIBC.

\section{Biochemical Estimations:}

Serum total calcium was estimated by modified Arsenazo method $^{8}$

Serum iron and TIBC were estimated by Ferrozin method ${ }^{9,}$ 10, 11. The biochemical data are expressed as mean \pm standard deviation. Statistical significance was analyzed using unpaired ' $\mathrm{t}$ ' test.

\section{Results}

Nine patients with thalassemia major receiving repeated blood transfusion (since the age of 1-2 years, after the diagnosis of thalassemia was confirmed) were studied to see their calcium and iron status.

Results were compared with a group nine normal healthy controls.

Table 1: Age distribution in cases and controls

\begin{tabular}{|c|c|c|}
\hline Group(n=9) & Cases & Controls \\
\hline Age $($ Yrs $)$ & $9.6 \pm 1.3$ & $10 \pm 1.5$ \\
Mean \pm SD & & \\
\hline$(\mathrm{P}>0.05-$ not significant $)$ & & \\
\hline
\end{tabular}

Table 1 shows that both the groups were statistically comparable $(\mathrm{P}>0.05)$ for the age distribution. 
Table 2: Comparison of serum total calcium, serum iron and TIBC between Cases and Control

\begin{tabular}{|c|c|c|}
\hline Biochemical parameters & Cases (9) Mean \pm SD & Controls (9) \\
Mean \pm SD
\end{tabular}

$\mathrm{P}$ value $<0.001$ (significant)

Table 2 shows serum total calcium levels are significantly decreased $(\mathrm{p}<0.001)$ in $\beta$-thalassemia patients as compared to normal healthy controls.

Results of the present study also demonstrate significant $(\mathrm{p}<0.001)$ increased levels of serum iron and decreased levels of TIBC in patients with thalassemia as compared to the controls.

\section{Discussion}

Present study demonstrates significantly increased levels of serum iron and decreased levels of TIBC in patients with thalassemia as compared to the controls indicating iron overload. Hypoparathyroidism due to iron overload is a common feature in patients of thalassemia ${ }^{12}$. Hypoparathyroidism (HPT) secondary to siderosis in thalassemia patients was first described by Gabriele in $1971^{13}$. A few studies have reported that some of the thalassemic patients on regular PCV infusion develop hypoparathyroidism, especially after 10 years of age ${ }^{12,14}$.

A number of possible mechanisms have been described to be responsible for glandular damage through iron overload. These include free radical formation and lipid peroxidation resulting in mitochondrial, lysosomal and sarcolemmal membrane damage ${ }^{15}$, number of surface transferrin receptors in the cell, and the ability of the cell to protect itself against inorganic iron ${ }^{16}$.

Aleem et $\mathrm{al}^{17}$ also observed hypoparathyroidism in patients of thalassemia. Several workers have reported reduced levels of PTH in patients with thalassemia ${ }^{12,}$ 17,18, 19. Further, hypoparathyroidism in turn is also known to cause hypocalcemia. In the present study, serum total calcium level in $\beta$-thalassemia patients is significantly lowered as compared to normal and may be a possible risk factor for bone ill-health. Autio et $\mathrm{al}^{18}$ observed that $61 \%$ of their patients with $\beta$-thalassemia had hypocalcemia. They further observed that these patients were benefited with vitamin D and calcium supplementations. Some study ${ }^{20,21}$ showed that supplementation of vitamin D and calcium to the thalassemia patients resulted in normocalcemia. Some workers have also reported that patients with thalassemia major have $24 \mathrm{hr}$ urinary calcium below the normal range ${ }^{19}$, 22. They further suggested that an early and effective treatment should be taken in order to improve their bone health.

In the present study serum total calcium level in $\beta$ thalassemia patient is significantly lowered as compared to normal and may be added risk factor for bone ill health and other hypocalcemia related complications.

\section{Conclusion}

From the present study, it can be concluded that on diagnosis as well as periodic assessment of thalassemia patients for hypocalcemia may be beneficial for minimizing complications related to hypocalcemia. Hypocalcemia if found in patients with thalassemia may be corrected by calcium and vitamin D rich food and 
supplementation. The limitation of the study is the small number of cases. It is now proposed to continue this work in a larger group along with the estimation of ionised calcium (Total calcium level may be affected by transport protein level), Parathyroid hormone, Vitamin D (Hypocalcaemia may result from inadequate intake of vitamin D) and serum ferritin level.

\section{Acknowledgement}

The authors are thankful to ICMR STS for the financial assistance to carry out this study. The authors are also thankful to Mrs Swati Raje, Statistician for the statistical analysis of this project.

\section{Conflict of interest: Nil}

\section{Permission from IRB: Yes}

\section{References}

1. Huisman THJ. The structure and function of normal and abnormal haemoglobins. Baillieres Clin Haematol. 1993 Mar;6(1):1-30

2. Thein SL. beta-Thalassemia. Baillieres Clin Haematol. 1993 Mar;6(1):151-75

3. Cazzola M, De Stefano P, Ponchio L, Locatelli F, Beguin Y, Dessi C, Barella S, Cao A, Galanello R. Relationship between transfusion regimen and suppression of erythropoiesis in beta thalassemia major. $\mathrm{Br} J$ Haematol. 1995 Mar;89(3):473-8

4. Cianciulli P. "Treatment of iron overload in thalassemia". Pediatr Endocrinol Rev. 2008 Oct;6 Suppl $1: 208-13$

5. Meropi Toumba and Nicosa Skordis. Osteoporosis syndrome in thalassemia major. $\mathrm{J}$ Osteoporos $2010 ; 2010: 537673$

6 Angelopoulos NG, Goula A, Rombopoulos G, Kaltzidou V, Katounda E, Kaltsas D, Tolis G.
Hypoparathyroidism in transfusion dependent patients with $\beta$-thalassemia J Bone Miner Metab. 2006;24(2):138-45

7. Salama OS, Al-Tonbary YA, Shahin RA, Eldeen OA. Unbalanced bone turnover in children with $\beta$ - thalassemia, haematology, 2006,11(3),197-202.

8. Biggs H.G., Moorehead, W.R. 2-Amino-2-methyl-1propanol as the Alkalizing Agent in an Improved Continuous-Flow Cresolphthalein Complexone Procedure for Calcium in Serum Clin Chem. 1974 Nov;20(11):1458-60

9. .N.W. Tietz, W.B. Saunders. Textbook of clinical chemistry. 1986

10. Artiss,Joseph D., Vinogradov S., Zak B., Spectrophotometric study of several sensitive reagents for serum iron. Clin Biochem. 1981 Dec;14(6):311-5

11. .N.W.Tietz. Fundamentals of clinical chemistry.1970, 658 .

12. De-Sanctis V, Vullo C, Bagni B, Chiccoli L. Hyperparathyroidism in beta thalassemia major: clinical and laboratory observations in 24 patients. Acta Haematol. 1992;88(2-3):105-8.

13. Gabriele O. Hypoparathyroidism associated with thalassemia. South Med J. 1971 Jan;64(1):115-6.

14. Rombos Y, Tzanetea R, Konstantopoulos K, Simitzis S, Zervas C, Kyriaki P, Kavouklis M, Aessopos A, Sakellaropoulos N, Karagiorga M, Kalotychou V,Loukopoulos D. Chelation therapy in patients with thalassemia using the orally active iron chelators deferiprone(L1) Haematologica. 2000 Feb;85(2):115-7

15. Gutteridge JM, Halliwell B. Iron toxicity and oxygen radicals. In: Hershko $\mathrm{C}$, editor. Iron chelating therapy. London: Baillière Tindall, 1989:195-256. 
16. Iancu T. Ultrastructural pathology of iron overload with special reference to endocrine glands. In: Pintor C, Corda R, De-Sanctis V, editors. Workshop on endocrine problems in thalassemia. Venezia: San Marco Scientific Publications, 1990:19-28.

17. Aleem A, AL-Momen AK, Al-Harakati MS, Hassan A, Al-Fawaz I. Hypocalcemia due to hypoparathyroidism in b-thalassemia major patients. Ann Saudi Med 2000;20(56):364-366.

18. Autio KA, Mait JE, Lesser M, Giardina PJ. Low bone mineral density in adolescents with $\beta$-thalassemia. J NY Acad Sci. 2005;1054:462.

19. Zamboni G, Marradi P, Tagliaro F, Dorizzi R, Tato L. Parathyroid hormone, calcitonin and vitamin D metabolites in beta-thalassemia major. Euro J Pediatr. 1986;145:133136.

20. Goyal M, Abrol P, Lal H. Parathyroid and Calcium Status in Patients with Thalassemia, Ind J Clin Biochem. $2010 ; 25(4): 385-387$

21. Dhouib N, Turki Z, Mellouli F, Ouederni
M, Yahiaoui S, Nagi S, Kouki R, Ben Slama
C, Bejaoui M. Hypocalcaemia due to hypoparathyroidism
in $\beta$-thalassemia major. A study of a new case. Tunis Med. 2011 Mar;89(3):302-4

22. Napoli N, En Carmina, Bucchieri S, Sferrazza C, Rini GB, Difede G. Low serum levels of 25-hydroxy vitamin D in adults with thalassemia major or intermedia. Bone.2006;38:888-892

\section{How to cite this article?}

Bandebuche S, Sagar V, Sontakke A. Serum total Calcium level in patients with Thalassemia. Int J Med Res Rev 2013;1(4):190194. doi.org/10.17511/ijmrr.2013.i04.07. doi: 10.17511/ijmrr.2013.i04.08 